\title{
Characteristics of cadmium ion sorption from aqueous solutions on copper(II) sulfide at different temperatures and $\mathrm{pH}$
}

\author{
A.V.Bulgakova ${ }^{1}$, D.S.Sofronov ${ }^{1}$, E.Yu.Bryleva ${ }^{1}$, V.A.Chebanov $^{1,2}$ \\ ${ }^{1}$ SSI "Institute for Single Crystals", STC "Institute for Single Crystals", \\ National Academy of Sciences of Ukraine, \\ 60 Nauky Ave., 61001 Kharkiv, Ukraine \\ ${ }^{2}$ V.Karazin Kharkiv National University, 4 Svobody Sq., 61022 Kharkiv, \\ Ukraine
}

\section{Received September 7, 2015}

\begin{abstract}
Characteristics of cadmium ion sorption from aqueous solutions on copper(II) sulfide at different temperatures and $\mathrm{pH}$ were investigated. The sorption process obeys to the Langmuir equation, which is used to calculate the sorption capacities of copper(II) sulfide. It is shown that the sorption capacity increases with increase of $\mathrm{pH}$ and decrease of temperature. The sorption capacity changes from $5.6 \mathrm{mg} / \mathrm{g}$ at $\mathrm{pH} 5$ and $308 \mathrm{~K}$ to $15.2 \mathrm{mg} / \mathrm{g}$ at $\mathrm{pH} 7$ and $288 \mathrm{~K}$. Optimization of the conditions permits to improve the copper(II) sulfide sorption capacity. The $\mathrm{pH}$ changes during the sorption obey to the Kurbatov equation with the sorption process being the ion exchange reaction.
\end{abstract}

Keywords: cadmium ion, sorption, sorption capacity.

\begin{abstract}
Исследованы особенности сорбции ионов кадмия сульфидом меди(II) из водных растворов при различных температурах и значениях $\mathrm{pH}$. Сорбционный процесс подчиняется уравнению Ленгмюра, по параметрам которого рассчитаны сорбционные емкости сульфида меди(II). Показано, что сорбционная емкость возрастает с увеличением $\mathrm{pH}$ и снижением температуры и варьируется от 5.6 мг/г при $\mathrm{pH} 5$ и $308 \mathrm{~K}$ до 15.2 мг/г при $\mathrm{pH} 7$ и $288 \mathrm{~K}$. Подбором оптимальных условий сорбции возможно значительно повысить сорбционную емкость сульфида меди(II). Изменение $\mathrm{pH}$ в процессе сорбции подчиняется уравнению Курбатова, что указывает на механизм ионного обмена ионов кадмия на протон поверхности сорбента.
\end{abstract}

Особливості сорбції йонів кадмію купрум(II) сульфідом з водних розчинів за різних температур та рН. А.В.Булгакова, Д.С.Софронов, К.Ю.Брильова, В.А.Чебанов .

Досліджено особливості сорбції йонів кадмію купрум(II) сульфідом з водних розчинів за різних температур та $\mathrm{pH}$. Сорбційний процес підпорядковується рівнянню Ленгмюра, за параметрами якого розраховано сорбційні ємності купрум(II) сульфіду. Показано, що сорбційна ємність зростає зі збільшенням $\mathrm{pH}$ та зниженням температури розчину та варіюється від 5.6 мг/г при рН 5 і $308 \mathrm{~K}$ до 15.2 мг/г при рН 7 і $288 \mathrm{~K}$. Вибір оптимальних умов сорбції дає можливість підвищити сорбційну ємність сульфіду купруму(II). Зміна рН під час сорбції підпорядковується рівнянню Курбатова, що вказує на механізм обміну йонів кадмію на протон поверхні сорбенту.

\section{Introduction}

Sorption is a widely used purification method for removal of cadmium ion from wastewater and natural water [1-12]. As sorbents for cadmium ion removal different natural and synthetic materials are used such as natural ferric hydroxide [7-9], 
pearlite [13], clinoptiolite [14], goethite and aluminium oxide [15], montmorillonite and kaolin [16], silicon dioxide [1], iron nanoparticles [12], modified activated carbon $[4,5]$, red mud [6], ion-exchange resin [10] et al.

The sorption capacity towards cadmium ions for synthetic silicon dioxide is $0.64 \mathrm{mg} / \mathrm{g}$, for synthetic ferric hydroxide is $7.41 \mathrm{mg} / \mathrm{g}$, for modified activated carbon is $4.05 \mathrm{mg} / \mathrm{g}$, for natural ferric hydroxide $10.00 \mathrm{mg} / \mathrm{g}$, for iron nanoparticles is $11.57 \mathrm{mg} / \mathrm{g}$, for pearlite is $3.05 \mathrm{mg} / \mathrm{g}$, for clinoptiolite is $2.08 \mathrm{mg} / \mathrm{g}$, for goethite is $4.82 \mathrm{mg} / \mathrm{g}$, for aluminium oxide is $0.0085 \mathrm{mg} / \mathrm{g}$.

Metal sulfides are promising compounds for production of the sorption materials [2, 17]. Such materials are available and their synthesis does not demand the complicated equipment. The sorption capacity towards cadmium ions for iron(II) sulfide is 7.37 to $22.94 \mathrm{mg} / \mathrm{g}$ at $\mathrm{pH}$ from 5 to 7 and temperature from 303 to $323 \mathrm{~K}$ [2]. The copper(II) sulfide sorption properties for cadmium ion removal have not been investigated.

The authors of some recent studies [3, 18,19 ] assumed that possible mechanism of metal ion incorporation in the metal sulphides corresponds with reactions:

$$
\begin{gathered}
\mathrm{CuS}+\mathrm{M}^{2+}=\mathrm{MS}+\mathrm{Cu}^{2+}, \\
2 \mathrm{CuSH}+\mathrm{M}^{2+}=(\mathrm{CuS})_{2} \mathrm{M}+2 \mathrm{H}^{+}, \\
\mathrm{CuSH}+\mathrm{MOH}^{+}=(\mathrm{CuS}) \mathrm{MOH}+\mathrm{H}^{+},
\end{gathered}
$$

where CuS and CuSH are sulphide surface groups and $\mathrm{M}^{2+}$ is a metal cation.

Initial sorbate concentrations, $\mathrm{pH}$ values and temperature of the solutions have an influence on the sorption values of the metal ions. Investigation of the temperature dependence of the sorption properties is very important because solubility of the sorbents increases with an increase of the temperature and stability of the surface complexes varies with the temperature [1-4, $10,12]$. In the works $[2,4,5,10,12]$ it is shown that the sorption of cadmium ions decreases with increase of the temperature. The temperature value also has an effect on electric surface properties of the sorbents and on the composition of the surface complexes. The sorption from solutions at the phase boundary "solid surface - electrolytic solution" depends on the boundary electric characteristics of the surface. Thus, the value of negative charge can make a positive electrostatic contribution to the sorption interaction between the surface and cations, and positive charge promotes the sorption of anions. The electric surface properties can be estimated from change in charge density with change in $\mathrm{pH}$ and the temperature [20].

The aim of this work was to investigate the effect of initial sorbate concentrations, $\mathrm{pH}$ values and temperature of the solutions on the value of cadmium ion sorption on copper(II) sulfide as well as to study the influence of the temperature and $\mathrm{pH}$ on the surface charge at the phase boundary "solid surface - electrolytic solution".

\section{Experimental}

For precipitation of copper(II) sulfide, $\mathrm{Cu}\left(\mathrm{NO}_{3}\right)_{2} \cdot 3 \mathrm{H}_{2} \mathrm{O}$, thiourea and potassium hydroxide from "Reachim" were used. All reagent used were analytical grade. All solutions were prepared with the distilled water.

Copper(II) sulfide precipitation was carried out as follows: $0.1 \mathrm{M}$ solution of potassium hydroxide was added to $100 \mathrm{ml}$ of $1 \mathrm{M}$ $\mathrm{Cu}\left(\mathrm{NO}_{3}\right)_{2}$ solution until $\mathrm{pH}$ reached 12 . Then thiourea solution in a molar ratio $c\left(\mathrm{Cu}^{2+}\right): c\left(\left(\mathrm{NH}_{2}\right)_{2} \mathrm{CS}\right) 1: 4$ was added. The resulting mixture was heated and boiled during one hour. At the end of synthesis the precipitate was filtered out, washed several times with distilled water and dried at the room temperature for $24 \mathrm{~h}$.

Sorption experiment was carried out at $288,298,308 \mathrm{~K}$ in thermostat during $24 \mathrm{~h}$. The mass of the sorbent was $0.1 \mathrm{~g}$, the volume and the concentration of the solution were $50 \mathrm{ml}$ and 10 to $100 \mathrm{mg} / \mathrm{g}$, respectively. $\mathrm{pH}$ values of 5,6 , and 7 were adjusted by solutions of $\mathrm{HNO}_{3}$ and $\mathrm{NaOH}$. After sorption the suspension was filtered. Equilibrium concentrations of cadmium ions were quantified by inductively coupled plasma atomic emission spectrometry (TRACE SCAN Advantage, Thermo Jarrell Ash).

The zero point of charge (ZPC) was determined by potentiometric titration of aqueous suspension of copper(II) sulfide [20]. Titration procedure consisted of adding about $50 \mathrm{ml}$ of the stock suspension of CuS (about $1 \mathrm{~g}$ of CuS) to the cell. The suspension of CuS was titrated by solutions of $\mathrm{NaOH}$ and $\mathrm{HCl}$. The $\mathrm{pH}$ range from 5 to 10 was covered. Equilibration was fast (less than $10 \mathrm{~min}$ ) in the high alkaline and in the acidic $\mathrm{pH}$ range but in the vicinity of the ZPC and near the equivalence point equilibration times as high as $2 \mathrm{~h}$ were observed. 


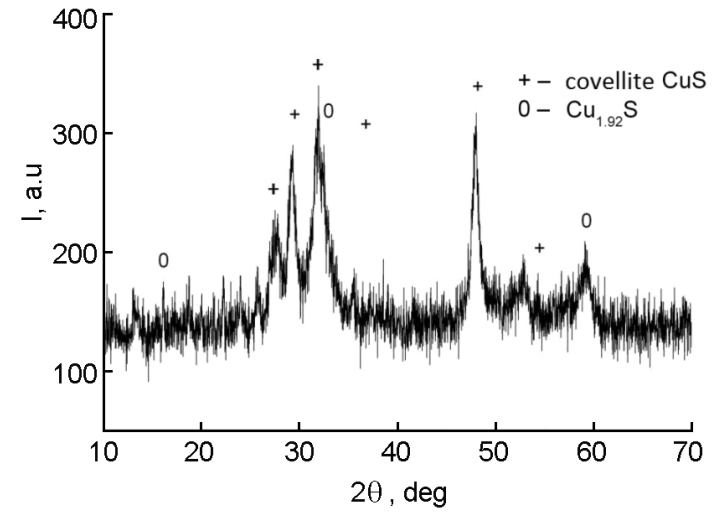

Fig. 1. X-ray diffraction patterns of copper(II) sulfide powder.

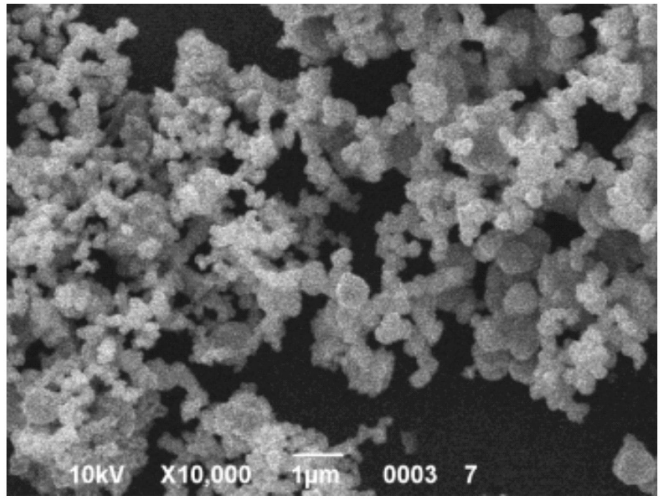

Fig. 2. SEM images of CuS particles.
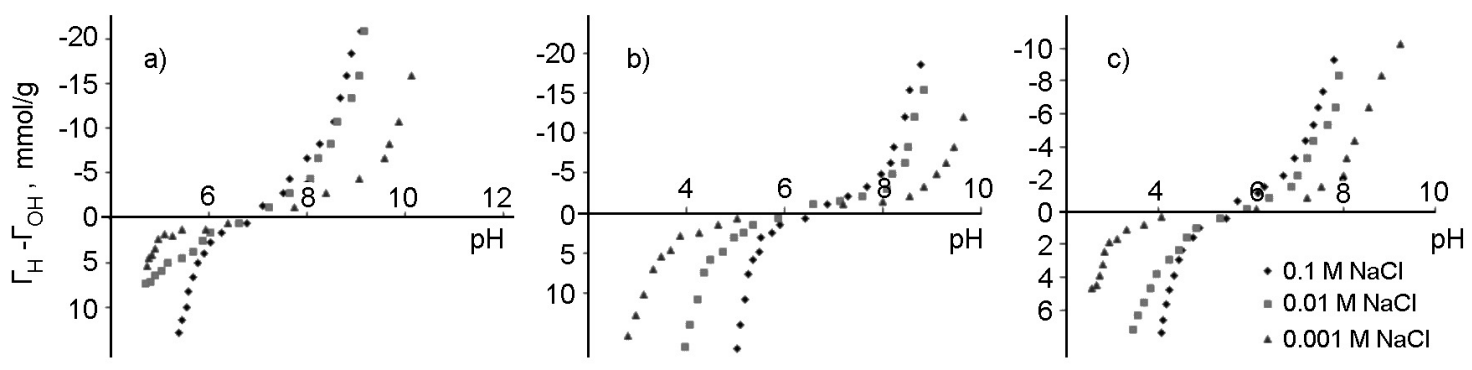

Fig. 3. Plots of the adsorption density (Г) of $\mathrm{OH}^{-}$and $\mathrm{H}^{+}$versus $\mathrm{pH}$ for CuS at 288 (a), 298 (b), 308 (c) $\mathrm{K}$.

Sodium chloride was chosen as supporting electrolyte and its concentrations were $0.001,0.01$, and $0.1 \mathrm{M}$. The intersection point of three potentiometric titration curves at ionic strengths of the supporting electrolyte (i.e. $0.001,0.01$, and $0.1 \mathrm{M}$ ) corresponds to the zero point of charge.

To obtain the FTIR spectra, SPECTRUM ONE (PerkinElmer) infrared spectrometer operating with spectral resolution of $1 \mathrm{~cm}^{-1}$ was used. Powder X-ray analysis was performed on powder diffractometer Siemens D500 $\left(\mathrm{Cu}-\mathrm{K}_{\alpha}\right.$ with a graphite monochromator in the secondary beam). Full X-ray diffraction patters were measured within the range of $10<2 \theta<90^{\circ}$ with a step of 0.02 and accumulation time of $10 \mathrm{sec}$ for each point. Study of the surface morphology of the powder obtained was carried out using a scanning microscope (SEM) JSM-6390LV. The $\mathrm{pH}$ values were measured by a $\mathrm{pH}$ meter pH-150 with a glass electrode and an auxiliary silver chloride electrode.

\section{Results and discussion}

CuS precipitation. Addition of thiourea to $\mathrm{Cu}\left(\mathrm{NO}_{3}\right)_{2}$ solution leads to formation of the black precipitate of copper(II) sulfide. Fig. 1 shows X-ray diffraction patterns of the obtained powder. According to the results of X-ray diffraction analysis, synthesized sample is CuS as covellite with impurity phase of $\mathrm{Cu}_{1.92} \mathrm{~S}$.

CuS powder consists of spherical particles with a mean diameter of $0.35 \mu \mathrm{m}$ (Fig. 2). Specific surface area of the powder was measured by the Brunauer-EmmettTeller method. The powder has specific surface area of $8.5 \mathrm{~m}^{2} / \mathrm{g}$.

The obtained powder was used for investigation of cadmium ion sorption from water solutions.

Plots of the adsorption density $(\Gamma)$ of $\mathrm{OH}^{-}$and $\mathrm{H}^{+}$(i.e. an excess of one species over the other) against $\mathrm{pH}$ determined by the Parks titration show that surface properties of copper(II) sulfide depend on temperature. $\mathrm{pH}_{\mathrm{ZPC}}$ values decrease with temperature increase and are $6.9,6.5$, and 5.7 at 288,298 , and $308 \mathrm{~K}$, respectively (Fig. 3). Such decrease of $\mathrm{pH}_{\mathrm{ZPC}}$ values with temperature increase was observed in the system $\mathrm{Al}_{2} \mathrm{O}_{3}-\mathrm{H}_{2} \mathrm{O}$ [21-23]. The authors concluded that this effect was due to proton desorption with the temperature increase.

It is known that solubility of the metal sulfides increases with increase in the temperature and decrease in $\mathrm{pH}$. Therefore, 

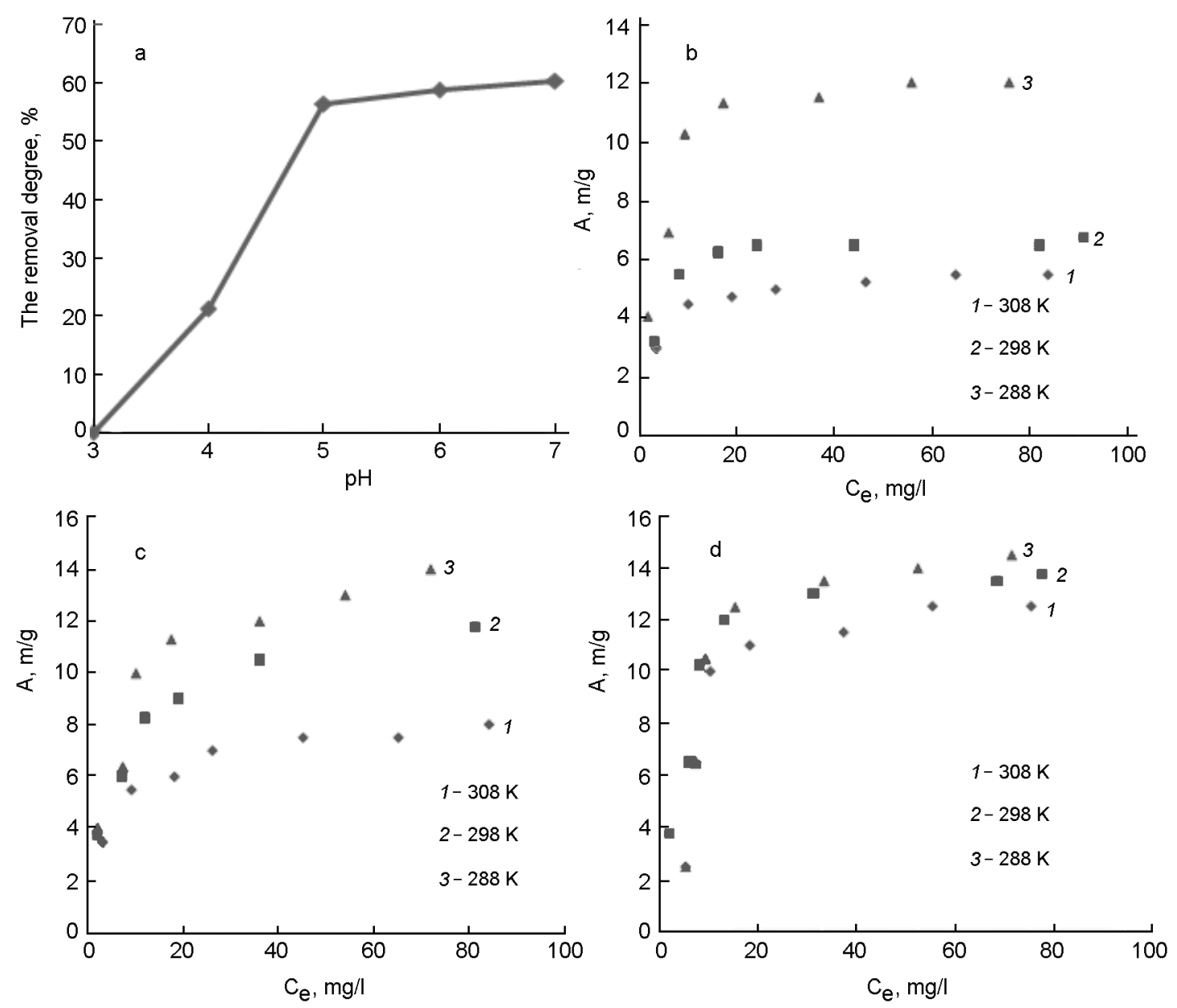

Fig. 4. PlotS of the removal degree of $\mathrm{Cd}^{2+}$ versus $\mathrm{pH}$ for CuS at $298 \mathrm{~K}$ (a) and isotherms of cadmium ion sorption on CuS at $\mathrm{pH} 5$ (b), 6 (c), 7(d).

when interpreting the $\mathrm{pH}_{\mathrm{ZPC}}$ shift data it is necessary to take into account that increase of the temperature causes the increase of the solubility of the studied sorbent with formation of hydrated compounds on its surface.

Sorption of $\mathrm{Cd}^{2+}$. Cadmium is primary in form of $\mathrm{Cd}^{2+}$ in the $\mathrm{pH}$ range of 5-7 [24]. The removal degree of $\mathrm{Cd}^{2+}$ increases with $\mathrm{pH}$ increase and exceeds $50 \%$ at $\mathrm{pH}$ more than 5 (Fig. 4a).

Cadmium ion sorption was studied as a function of $\mathrm{pH}$, temperature and sorbate concentration. The obtained sorption isotherms show that the sorption of cadmium ions decreases with increase of the temperature. $\mathrm{pH}_{\mathrm{ZPC}}$ shift in more acidic range with increase of the temperature induces the surface charge density changes. It leads to change in the electrostatic component of the free energy for cadmium ion sorption and thereby in the sorption value. In addition, the sorption of cadmium ions increases with
Table 1. Amount of copper(II) ions released during the sorption of cadmium ions on copper(II) sulfide at pH 5 .

\begin{tabular}{||c|c|c|c|c|c||}
\hline \hline \multicolumn{2}{|c|}{$288 \mathrm{~K}$} & \multicolumn{2}{c|}{$298 \mathrm{~K}$} & \multicolumn{2}{c||}{$308 \mathrm{~K}$} \\
\hline $\begin{array}{c}A, \\
\mathrm{mg} / \mathrm{g}\end{array}$ & $\begin{array}{c}c(\mathrm{Cu}(\mathrm{II})), \\
\mathrm{mg} / \mathrm{g}\end{array}$ & $\begin{array}{c}A, \\
\mathrm{mg} / \mathrm{g}\end{array}$ & $\begin{array}{c}c(\mathrm{Cu}(\mathrm{II})), \\
\mathrm{mg} / \mathrm{g}\end{array}$ & $\begin{array}{c}A, \\
\mathrm{mg} / \mathrm{g}\end{array}$ & $\begin{array}{c}c(\mathrm{Cu}(\mathrm{II})), \\
\mathrm{mg} / \mathrm{g}\end{array}$ \\
\hline 3.6 & 0 & 2.9 & 0.2 & 2.7 & 0.5 \\
6.1 & 0 & 4.4 & 0.2 & 4.0 & 0.6 \\
9.1 & 0 & 4.7 & 0.2 & 4.2 & 0.6 \\
10.0 & 0 & 4.8 & 0.3 & 4.4 & 0.6 \\
10.2 & 0 & 5.3 & 0.3 & 4.6 & 0.7 \\
10.7 & 0 & 5.8 & 0.2 & 4.9 & 0.6 \\
10.9 & 0 & 6.0 & 0.2 & 5.3 & 0.6 \\
\hline \hline
\end{tabular}

increase in the initial $\mathrm{pH}$ value of the aqueous solution.

The amount of copper(II) ions released during the sorption of cadmium ions increases with an increase in the temperature and does not depend on the amount of cad- 


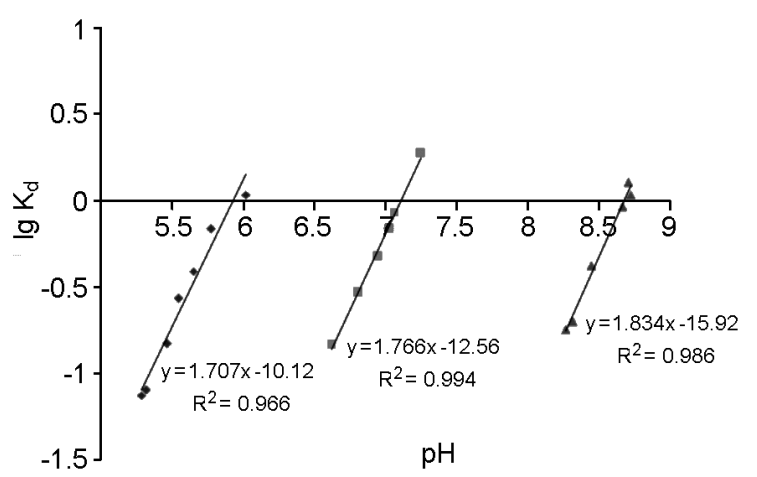

Fig. 5. Plots of $\lg K_{d}$ versus $\mathrm{pH}$ for cadmium ion sorption at $298 \mathrm{~K}$.

mium ions sorbed (Table 1). Therefore, the sorption mechanism does not follow the reaction (1). The amount of sulfur released during the sorption $(0.6 \mathrm{~mol} / \mathrm{g}$ at $\mathrm{pH} 5$ and $308 \mathrm{~K})$ confirms the same, because it coincides with the amount of copper(II) ions. Thus, copper(II) ions and sulfide ions released during the sorption of cadmium ions are the results of copper(II) sulfide dissolution.

The $\mathrm{pH}$ changes accompany the cadmium ion sorption. The $\mathrm{pH}$ values after sorption $\left(\mathrm{pH}_{\mathrm{eq}}\right)$ decrease with increase of the cadmium ions sorption (Table 2). It shows that the protons previously sorbed on CuS exchange with cadmium ions from aqueous solution. Similar changes in $\mathrm{pH}$ with cadmium ions sorption was observed in the works [18, 19]. Therefore, the reactions of the ion exchange (2) and (3) are possible.

After calculating the ratio between the numbers of released protons and sorbed cadmium ions, it is possible to determine whether the reaction of the ion exchange (2) or (3) takes place. Such information can be obtained from linear plots of $\operatorname{lgK}_{d}$ versus $\mathrm{pH}$ according to the equation proposed by Kurbatov et al. [15]:

$$
\lg K_{d}=n \mathrm{pH}+C,
$$

where $K_{d}$ is the distribution coefficient ( $\left.K_{d}=A / C_{e}\right), A$ is the amount of cadmium ions sorbed per $1 \mathrm{~g}$ of the sorbent, $C_{e}$ is the equilibrium concentration and $n$ is the slope of the line which shows the stoichiometry of the ion exchange reaction between $\mathrm{H}^{+}$and cadmium ions. Plots of $\lg K_{d}$ versus $\mathrm{pH}$ for the cadmium ion sorption at $298 \mathrm{~K}$ are shown in Fig. 5.

The values of $n$ given in Table 3 are in the range between 1.2 and 1.9 that is at this conditions 1.2 to $1.9 \mathrm{~mol}$ of protons are
Table 2. $\mathrm{pH}$ values after sorption $\left(\mathrm{pH}_{\mathrm{eq}}\right)$

\begin{tabular}{||c|c|c|c|c|c||}
\hline \multicolumn{2}{|c|}{$\mathrm{pH} 5$} & \multicolumn{2}{c|}{$\mathrm{pH} 6$} & \multicolumn{2}{c||}{$\mathrm{pH} 7$} \\
\hline $\mathrm{pH}_{\mathrm{eq}}$ & $\begin{array}{c}A, \\
\mathrm{mg} / \mathrm{g}\end{array}$ & $\mathrm{pH}_{\mathrm{eq}}$ & $\begin{array}{c}A, \\
\mathrm{mg} / \mathrm{g}\end{array}$ & $\mathrm{pH}_{\mathrm{eq}}$ & $\begin{array}{c}A, \\
\mathrm{mg} / \mathrm{g}\end{array}$ \\
\hline 6.02 & 3.3 & 6.75 & 3.8 & 8.79 & 3.8 \\
5.78 & 5.0 & 6.56 & 6.3 & 8.73 & 6.5 \\
5.65 & 5.3 & 6.53 & 10.3 & 8.71 & 10.4 \\
5.55 & 5.5 & 6.45 & 11.0 & 8.67 & 12.0 \\
5.47 & 6.0 & 6.31 & 11.5 & 8.45 & 13.0 \\
5.32 & 6.5 & 6.12 & 11.8 & 8.32 & 13.5 \\
5.29 & 6.8 & - & - & 8.27 & 13.8 \\
\hline
\end{tabular}

Table 3. Values of $n$ obtained from the Kurbatov equation for cadmium ion sorption on copper(II) sulfide at different values of temperature and $\mathrm{pH}$

\begin{tabular}{|c|c|c|c||}
\hline$T, \mathrm{~K}$ & $\mathrm{pH} 5$ & $\mathrm{pH} 6$ & $\mathrm{pH} 7$ \\
\hline $288 \mathrm{~K}$ & 1.2 & 1.3 & 1.3 \\
$298 \mathrm{~K}$ & 1.7 & 1.8 & 1.8 \\
$308 \mathrm{~K}$ & 1.9 & 1.9 & 1.9 \\
\hline
\end{tabular}

Table 4 . Sorption capacities $\left(A_{m}\right)$ and the Langmuir coefficients $\left(K_{b}\right)$ for cadmium ion sorption on copper(II) sulfide

\begin{tabular}{||c|c|c|c|c|c|c|}
\hline \multirow{2}{*}{$T, \mathrm{~K}$} & \multicolumn{2}{|c|}{$\mathrm{pH}=5$} & \multicolumn{2}{c|}{$\mathrm{pH}=6$} & \multicolumn{2}{c|}{$\mathrm{pH}=7$} \\
\cline { 2 - 7 } & $\begin{array}{c}A_{m}, \\
\mathrm{mg} / \mathrm{g}\end{array}$ & $\begin{array}{c}K_{b}, \\
\mathrm{l} / \mathrm{g}\end{array}$ & $\begin{array}{c}A_{m}, \\
\mathrm{mg} / \mathrm{g}\end{array}$ & $\begin{array}{c}K_{b}, \\
1 / \mathrm{g}\end{array}$ & $\begin{array}{c}A_{m}, \\
\mathrm{mg} / \mathrm{g}\end{array}$ & $\begin{array}{c}K_{b}, \\
1 / g\end{array}$ \\
\hline $288 \mathrm{~K}$ & 13.3 & 152 & 14.3 & 188 & 15.2 & 257 \\
$298 \mathrm{~K}$ & 9.0 & 184 & 11.4 & 221 & 13.7 & 335 \\
$308 \mathrm{~K}$ & 5.6 & 236 & 7.3 & 261 & 13.0 & 342 \\
\hline
\end{tabular}

Table 5. The Gibbs energy changes ( $\mathrm{kJ} / \mathrm{mol})$ for cadmium ion sorption on copper(II) sulfide

\begin{tabular}{|c|c|c|c||}
\hline$T, \mathrm{~K}$ & $\mathrm{pH} 5$ & $\mathrm{pH} 6$ & $\mathrm{pH} 7$ \\
\hline 288 & -12.0 & -13.0 & -14.2 \\
298 & -12.5 & -13.4 & -14.9 \\
308 & -13.1 & -13.8 & -14.9 \\
\hline
\end{tabular}

released from copper(II) sulfide surface when $1 \mathrm{~mol}$ of cadmium ion is sorbed. Thus both reactions (2) and (3) are possible.

The Langmuir isotherms were used for the interpretation of the ion exchange reactions. The values of sorption capacity $\left(A_{m}\right)$ and Langmuir coefficient $\left(K_{b}\right)$ for the sorption of cadmium ions on copper(II) sulfide are given in Table 4 . The values of the sorption capacity decrease with an increase in the temperature but increase with increase of $\mathrm{pH}$ from 5 to 7 . The $K_{b}$ values increase with increase of the temperature at $\mathrm{pH}$ from 5 to 7 . 
In order to ascertain the nature of cadmium ion sorption on copper(II) sulphide, changes in the Gibbs free energy $(\Delta G)$ were calculated according to the following equation:

$$
\Delta G=-R T \ln K_{b}
$$

Only negative values of the Gibbs free energy were obtained. It is evidence of the spontaneous nature of the sorption (Table 5). Similar values of the Gibbs free energy were found for cadmium ion sorption on ion exchange resin $[3,10]$ and rice husk ash [26].

\section{Conclusions}

The process of cadmium ion sorption on copper(II) sulfide from aqueous solutions was investigated. The sorption increases with increase of $\mathrm{pH}$ and decrease of temperature. The sorption capacity of cadmium ions on copper(II) sulfide changes from $5.6 \mathrm{mg} / \mathrm{g}$ (at pH 5 and $308 \mathrm{~K}$ ) to $15.2 \mathrm{mg} / \mathrm{g}$ (at $\mathrm{pH} 7$ and $288 \mathrm{~K}$ ). The Kurbatov equation is applicable to fit the experimental data indicating the ion exchange mechanism.

\section{References}

1. S.Mustafa, M.Waseem, A.Naeem et al., Desalination, 255, 148 (2010).

2. S.Mustafa, S.Misbahud, D.Sammad et al., Chin.J.Chem., 28, 1153 (2010).

3. M.Erdem, A.Ozverdi, Separat. and Purif. Techn., 51, 240 (2006).

4. X.Huang, N.Gao, Q.Zhang, J. Environ. Sci., 19, 1287 (2007).

5. Y.Kang, M.Poon, P.Monash et al., Korean J. Chem.Eng., 30, 1904 (2010).

6. L.Luo, C.Ma, Y.Ma, Environ Pollut., 159(5), 1108 (2011).
7. K.V.Ragnarsdottir, C.R.Collins, D.M.Sherman, Mineral. Mag., 62A, 650 (1998).

8. D.A.Dzombak, M.M.Francois, J. Colloid and Interf. Sci., 112, (1986).

9. N.Salami, F.A.Adekola, Bull.Chem.Soc. Ethiop., 16(1), 7 (2002)

10. F.Wang, L.J.Wang, J.S.Li, Trans. Nonfer. Met.Soc., 19, 740 (2009).

11. H.Benaissa, M-A.Elouchdi, in: Proc. of Twelfth Intern. Water Technology. Conf., Alexandria, Egypt 1 (2008), p.122.

12. H.K.Boparai, M.Joseph, D.M.O'Carroll, J. Hazard. Mater., 27, 8 (2010).

13. T.Mathialagan, T.Viraraghavan, J.Hazard. Mater. B, 94, 291 (2002).

14. V.O.Vasylechko, G.V.Gryshchouk, Yu.B.Kuz'ma et al., Micropor. Mesopor. Mater., 60, 183 (2003).

15. S.K.Srivastava, G.Bhattacharjee, R.Tyagi et al., Environ. Technol. Lett., 9, 1173 (1988).

16. S.K.Srivastava, R.Tyagi, N.Pal, Environ. Technol. Lett., 10, 275 (1989).

17. Y.Loo, A.Yoong, P.Lay et al., Advan. Mat. Res., 356-360, 537 (2012).

18. T.Jong, D.L.Parry, J.Colloid Interf. Sci., 61, 275 (2004).

19. J.M.Moore, S.Ramamoorthy, Heavy Metals in Natural Waters, Springrer-Verlag Corporation, New York (1984).

20. G.A.Parks, P.L.de Bruyn, J.Phys.Chem., 66, 967 (1962).

21. W.E.Halter, Geochim. et Cosmochim. Acta, 63, 3077 (1999).

22. P.H.Tewari, A.W.McLean, J.Colloid Interf. Sci., 40, 267 (1972).

23. S.Mustafa, B.Dilara, Z.Neelofer et al., J. Colloid and Interf. Sci., 204, 284 (1998).

24. V.A.Nazarenko, V.P.Antonovich, E.M.Nevskaya, Metal Ions Hydrolysis in Dilute Solutions, Atomizdat, Moscow (1979) [in Russian].

25. M.H.Kurbatove, G.B.Wood, J.D.Kurbatove, J. Phys.Chem., 55, 1170 (1951).

26. V.C.Srivastava, I.D.Mall, I.M.Mishra, Chem. Eng. J., 132, 267 (2007). 